\title{
The Influence of Principal Managerial Activities, Job Satisfaction, and Organizational Culture on the Performance of Elementary School Teachers in Hampang Sub-district
}

Budi Hartono *, Sulaiman, Suhaimi

Master Program of Educational Management, Universitas Lambung Mangkurat, Banjarmasin 70123, Indonesia

\begin{tabular}{|c|c|}
\hline ARTICLE INFO & A B STR ACT \\
\hline \multirow[t]{2}{*}{$\begin{array}{l}\text { Article history } \\
\text { Submission: November } \\
\text { 20I9 } \\
\text { Revised: March } 2020 \\
\text { Accepted: March } 2020\end{array}$} & $\begin{array}{l}\text { This study aims to determine and describe the direct/indirect effects of Principal } \\
\text { Managerial Activities, Organizational Culture, and Job Satisfaction on the } \\
\text { Performance of Primary School Teachers in the Hampang Sub-district. This is a } \\
\text { survey research with data quantitatively obtained from a sample of } 92 \text { people by } \\
\text { using questionnaires that have met the validity and reliability test requirements. } \\
\text { Furthermore, path analysis with multiple regression methods was used to test for } \\
\text { hypotheses. The results showed that (I) Principal managerial activities, } \\
\text { organizational culture, and teacher job satisfaction directly affected performance by } \\
63.5 \% \text {, 35.4\%, and } 75.5 \% \text {, respectively. (2) Principal's managerial and } \\
\text { organizational culture directly influenced job satisfaction by } 63.1 \% \text {, and } 51.6 \% \text {. } \\
\text { (3) Principal's managerial activities and organizational culture indirectly affected } \\
\text { teachers' performance through job satisfaction by } 47.6 \% \text {, and } 38.9 \% \text {. }\end{array}$ \\
\hline & $\begin{array}{l}\text { (C) (1) () } 2019 \text { The Authors. Journal of K6, Education, and Management } \\
\text { (j-K6EM). ISSN: 2580-2135. Published by Graduate Program of } \\
\text { Educational Management, Universitas Lambung Mangkurat, }\end{array}$ \\
\hline
\end{tabular}

*Correspondence: Budi Hartono; E-mail: abinyanazla@gmail.com 


\section{Introduction}

In the educational process, the teacher occupies a strategic position and plays a key role in teaching and learning activities, meaning that they need to be able to assist students in obtaining knowledge and skills following educational objectives. The teacher plays a major role in fostering students with good mental and intellectual attitude. Good teacher performance is essential in providing quality education (Aslamiah, Agustina, \& Saleh, 2019). Wijaya and Rusyan (1994) stated that the teacher is an educator, and role model, while the principal is a school manager.

School principal, as a school manager, needs to be able to organize and create a good organizational culture to increase job satisfaction and teacher performance. According to Suhaimi and Khalik (2018), the school principal needs to inspire, motivate, and be a driving force in school development. The principal is a person with the ability to lead the school and professionals in the field of education. However, not all school principals meet the specified criteria, some prioritize the class or rank that is lived through the work period. Therefore, teachers and principals need to possess adequate behavior and good performance.

The initial observations obtained from thirteen elementary schools consisting of I20 teachers in the Hampang sub-district, found incomplete teacher performance in carrying out their duties and functions such as, in planning teaching programs, implementing learning activities, carrying out assessments, compiling, and implementing improvement programs and developing the teaching field. From the observations made in these schools, it was found that most of the teachers had a Learning Implementation Plan (RPP), which were not utilized, while some had none and depended on textbooks or students' work.

For example, the profiles of teachers with less perfect performance were those with monotonous and poor preparation. Furthermore, those that only utilized the teaching preparation method failed to use the required curriculum references, and are inconsistent in the implementation of the lesson plan (RPP) scenarios prepared and in the learning process. This because they teach based on their past experiences, which they have memorized. Therefore, changes associated with new learning methods, use of media, and assessment systems are not implemented. The assessment activities are carried out routinely without reflections or follow up. The success of the implementation of education is very much determined by the readiness of teachers in preparing their students through teaching and learning activities. The quality of the education process depends on the creativity and innovation that the teacher (Rahmawati, Ahmad, \& Suriansyah, 2019).

The principals of the thirteen elementary schools rarely met to discuss ways of improving teacher performance regarding the program, implementation, and supervision. This made the teachers less serious in preparing RPP, implementing effective and innovative learning methods, conducting authentic assessments of students, with poor relationships with the principal. The things that contribute to performance are communication that represents the main factors in improving the quality of work because a job is inseparable from the adequacy and accuracy of information about the job, opportunities that are increased vertically and horizontally (Suriansyah, 2014).

Following the subject matter above, the desired objectives in this study are to:

I. Describe the principal managerial activities, cultural organization, job satisfaction, and performance of elementary school teachers in the Hampang sub-district.

2. Analyze the direct effect of the principal's managerial activities on the performance of teachers in the elementary school in the Hampang sub-district.

3. Analyze the direct influence of organizational culture on teacher 
performance in primary schools in the Hampang sub-district.

4. Analyze the direct effect of teacher job satisfaction on teacher performance in primary schools in the Hampang subdistrict.

5. Analyze the direct effect of the principal's managerial activities on teacher job satisfaction in elementary schools in the Hampang sub-district.

6. Analyzing the direct influence of organizational culture on job satisfaction of elementary school teachers in the Hampang sub-district.

7. Analyzing the indirect effect of the principal's managerial activities on the performance of elementary school teachers in the Hampang sub-district through the teacher job satisfaction variable.

8. Analyzing the indirect effect of organizational culture on the performance of elementary school teachers in the Hampang sub-district through the variable teacher job satisfaction.

The hypotheses of this research are as follows:

I. There is a direct influence on the principal's managerial activities on the performance of teachers in the elementary school in the Hampang sub-district.

2. There is a direct influence of organizational culture on teacher performance in primary schools in the Hampang sub-district.

3. There is a direct effect on teacher job satisfaction on teacher performance in primary schools in the Hampang subdistrict.
4. There is a direct influence on the principal's managerial activities on the job satisfaction of teachers in primary schools in the Hampang sub-district.

5. There is a direct influence of organizational culture on job satisfaction of elementary school teachers in the Hampang sub-district.

6. There is an indirect effect on the principal's managerial activities on the performance of elementary school teachers in the Hampang sub-district through the variable teacher job satisfaction.

7. There is an indirect effect of organizational culture on the performance of elementary school teachers in Hampang sub-district through the variable teacher job satisfaction

\section{Methodology}

This is quantitative research with correlational and survey design approaches. This study was also designed to explain the influence of principals' managerial activities and organizational culture on job satisfaction to improve the performance of elementary school teachers in the Hampang subdistrict. Data were obtained from a sample of 92 teachers from a population study of 120 teachers of elementary school teachers in the Hampang sub-district. Sampling-based on Krejcie's table. While path analysis using SPSS was used for its analysis. The results analyzed the Relationships between Principal Managerial Activities (XI), Organizational Culture (X2), Job Satisfaction (Z), and Teacher Performance (Y).

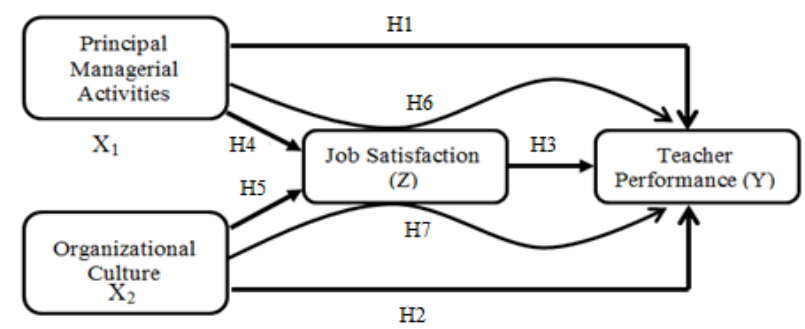

Figure I. Relationship Diagram between Variables XI, X2, Z, Y. 


\section{Result and Discussion}

\section{Direct Effect of Principal Managerial Activities on Teacher Performance}

The results of the path analysis on the relationship between Principal Managerial Activities (XI) and Teacher Performance (Y) obtained an R-value of 0.635 , which shows a strong relationship between the variables. The relationship between Principal Managerial Activities (XI) and Teacher Performance (Y) was 0.033 , with a significant value of 0.05 , therefore, $\mathrm{H}_{0}$ is rejected. In conclusion, the Principal Managerial Activity variable has a significant influence on teacher performance.

According to Mulyasa (2004), the impact associated with carrying out tasks based on the managerial functions of school principals is strong leadership, effective management of educational staff, quality culture, compact teamwork, intelligent and dynamic independent participation of schools and community members, transparent management, willingness to change (psychological and physical), evaluation, continuous improvement, responsive and anticipatory requests to needs, accountability, and sustainability.

The school principal sustains education through adequate management and by utilizing all school resources to achieve quality educational goals.

Effective and efficient school management systems tend to improve the quality of education and vice versa. Furthermore, the principal is instrumental in determining the continuity of the education process in schools (Idris, 2005). Therefore, the implementation of the activities related to the principal's managerial skills needs to be immediately developed because it is one of the main factors that determine teachers' performance.

The school principal plays the roles and responsibilities of an education manager. They are required to have managerial skills that are following the scope of educational institutions to achieve set goals. Furthermore, the principal is responsible for planning, organizing, implementing, leading, and controlling all school activities while utilizing all resources (human and material) to achieve educational goals.

Teacher performance greatly affects the continuity of the whole learning process in the classroom and the quality of graduates. Bafadal (2006), stated that all components that influence the formation of learning experiences such as programs, students, facilities and infrastructure, funds, community environment, school principal leadership, are not useful for students when they are not supported by professional teachers. Furthermore, Aslamiah (2016) defined teacher performance as a result achieved by teachers in carrying out some of its main tasks, namely planning, implementing, managing, and assessing students learning progress. Damai, Efendi, \& Sulaiman (2019), categorized these performances as good, high commissioners, disciplined, creative, friendly, honest and responsible in developing learning materials, as well as in working with all school members.

Professional teachers are the result of the application of organizational culture that is properly regulated by the principal through adequate managerial skills. Puspitasari (2015), in her book entitled "Managerial Ability in Improving Teacher Performance," explained that the role of the principal as a leader is influential on the success of the school and in improving teacher performance.

\section{The direct influence of organizational culture on teacher performance \\ The results of the path analysis of the} relationship between Organizational Culture (X2) and Teacher Performance $(\mathrm{Y})$ obtained an Rvalue of 0.345 , which means that there is a weak and unidirectional relationship between both variables. When the significant value is $0.00 \mathrm{I}$ with $0.000<0.05$, then $\mathrm{H}_{0}$ is rejected. Therefore, it is concluded that organizational culture variables have a significant influence on teacher performance. The coefficient of determining the influence of Organizational Culture obtained a value of 0.125 . This shows that the principal managerial activities influence teacher performance by $12.5 \%$. Wirawan (2008) stated that organizational culture influences the attitudes and behavior of members, which determines their performance.

Suhardan (2010) stated that the culture of school organizations fosters how quality and performance are carried out by its members. Robbins (200I) stated that organizational culture is an intervention variable, with member's used to form its overall subjective perception. The results of this study are in line with Brown's theory 
20I2), which stated that "A strong organizational culture leads to the achievement of goals and objectives. Its members, with all their resources, efforts, initiative, and enthusiasm, unite in the same direction by utilizing the resources properly. Therefore, organizational performance is achieved in a healthy and motivational process. Therefore, a strong organizational culture will have an impact on performance.

\section{The Direct Effect of Teacher Job Satisfaction on} Teacher Performance

The path analysis results of the relationship between Job Satisfaction ( $Z$ ) with Teacher Performance $(\mathrm{Y})$ obtained an R-value of 0.755 , which means that there is a very strong and unidirectional relationship between both variables. The significant value of their relationship is 0,000 $<0.05$ then $\mathrm{H}_{0}$ is rejected. Therefore, it is concluded that the teacher job satisfaction variable has a significant effect on performance. For teachers, intrinsic satisfaction comes from activities in the classroom. Daily interactions with student form help them to understand the presence or absence of student learning outcomes.

According to Perie (1997), student characteristics and teacher perceptions of classroom environment settings are also intrinsic factors that influence satisfaction. Intrinsic factors play an important role in motivating individuals to teach, and many choose the profession because they enjoy teaching students and prefer working with young people. Extrinsic factors are associated with teacher job satisfaction, which includes salary, support from school administrators, safety, and the availability of resources.

The results of this study are in line with the research conducted by Darwito (2008), which stated that job satisfaction has a positive effect on employee performance. Furthermore, Ni Wayan Kurnia Widya Wati, Ahmad Suriansyah, \& M. Rustam Effendi (2017) stated that satisfied lecturers are more likely to be involved in organizations that increase productivity, while the unsatisfied ones tend to assist in achieving set goals.
Direct Effect of Principal's Managerial Activities on Teacher Job Satisfaction

The results of the path analysis of the relationship between Principal Managerial Activities (XI) and Teacher Job Satisfaction (Z) obtained an R-value of $0.63 \mathrm{I}$ which means that there is a strong and direct relationship between both variables. The significant value of $0.00 \mathrm{I}$ on $0.000<0.05$ was obtained, therefore, $\mathrm{H}_{0}$ is rejected. It is concluded that the Principal Managerial Activity variable has a significant direct effect on teacher job satisfaction.

The principal, as a manager in the school, is the driving force for implementing learning activities. Principals are required to possess managerial skills to manage human resources, especially teachers. One of the effectiveness of teacher performance is when they feel satisfied with their work. Robbins (200I) stated that job satisfaction has a large effect on performance and increases productivity.

The factors driving the emergence of job satisfaction in many schools are based on the implementation of the principal's managerial skills. The implementation of concept skills possessed by the principal helps the teacher to be creative, initiative, and independent in developing their assignments at school. Furthermore, the implementation of the principals' conceptual abilities encourages teachers to act aggressively, innovatively, increase cooperation and dares them to take risks. It also encourages teachers to derive pride from educating students and encourages the principal to assist teachers in the form of communication patterns.

The implementation of the principal's technical skills helps teachers to develop themselves and be able to carry out their tasks effectively to achieve various promotions. Teachers possess administrative skills for the educational process to run smoothly and orderly. The results of this study are in line with the research conducted by Darwito (2008), which stated that leadership style positively influences performance. 
Direct Influence of Organizational Culture on Job Satisfaction

The path analysis results of the relationship between Organizational Culture (X2) and Teacher Job Satisfaction $(Z)$ obtained an R-value of 0.516 , which means that there is a moderate and direct relationship between both variables. The significant value is 0,000 less than 0.05 , therefore, $\mathrm{H}_{0}$ is rejected.

Wirawan (2008) stated that a conducive organizational culture creates, improves, and maintains high performance, with improved job satisfaction. The school organizational culture is correlated with the development of student motivation, learning achievement, as well as the job satisfaction and productivity of teachers.

Organizational culture is a set of assumptions, beliefs, values, and norms which are shared by its members. The value of togetherness to move forward in developing the organization is the core of its culture. This understanding tends to affect the creation of effective communication between the teacher and principal, colleagues, and community.

Teachers become more creative in developing work because schools possess a framework of reference norms that are adhered together. Furthermore, they do not hesitate to innovate students because they are ready to criticize and be criticized for the progress of their learning activities. With the organizational culture, teachers feel valued with pride for the work conducted and obtain justice because each member of the organization is equally valued following their achievements with agreed norms and values.

With the appropriate awards, it is hoped that teachers are going to be more active and creative in developing their learning skills. Furthermore, their values are shown in line with the organization, while organizational culture helps them to overcome problems for a pleasant working condition. Teachers satisfied with their work attend to possess good performance.
Indirect Effects of Principal Managerial Activities on Elementary School Teacher Performance

The path analysis of the indirect relationship of the Principal's Managerial Activities (XI) to Teacher Performance (Y) through teacher job satisfaction (Z) which was obtained by multiplying the path coefficient of the direct effect of variables XI on Z (P4) with Z on $\mathrm{Y}$ (P3), as follows $0.63 \mathrm{I} \times 0.755=0.476$. This means that there is an indirect positive effect between the Principal Managerial Activity variable (XI) and the Teacher Performance (Y) through Job Satisfaction (Z) of 0.476 .

The principal plays the role and responsibilities of an education manager with skills that are appropriate to the situation and conditions of schools to achieve its goals. The principal is responsible for planning, organizing, implementing, directing, and controlling all school activities and utilizing all resources (human and material) to achieve set educational goals.

The teacher's job satisfaction variable causes a decrease in the direct influence of the principal's managerial activity from 0.635 to 0.476 .

\section{The Indirect Effect of Organizational Culture on The Performance of Elementary School Teachers}

The results of path analysis on the indirect relationship of Organizational Culture (X2) on Teacher Performance $(\mathrm{Y})$ through job satisfaction (Z) was obtained by multiplying the path coefficient of the direct influence of variables XI with $\mathrm{Z}$ (P5) and $\mathrm{Z}$ with $\mathrm{Y}$ (P3), as follows 0.516 x $0.755=0.389$. This means that there is an indirect positive influence between the variable Organizational Culture (X2) and the Teacher Performance variable (Y) through Job Satisfaction (Z) of 0.389 .

The existence of teacher job satisfaction variables causes an increase in the direct influence of organizational culture on the performance of elementary school teachers in Hampang Subdistrict, from 0.354 to 0.389 . 
Professional teachers are the result of the application of organizational culture, which is regulated by the principal through adequate managerial skills in terms of concept, human, and good techniques.

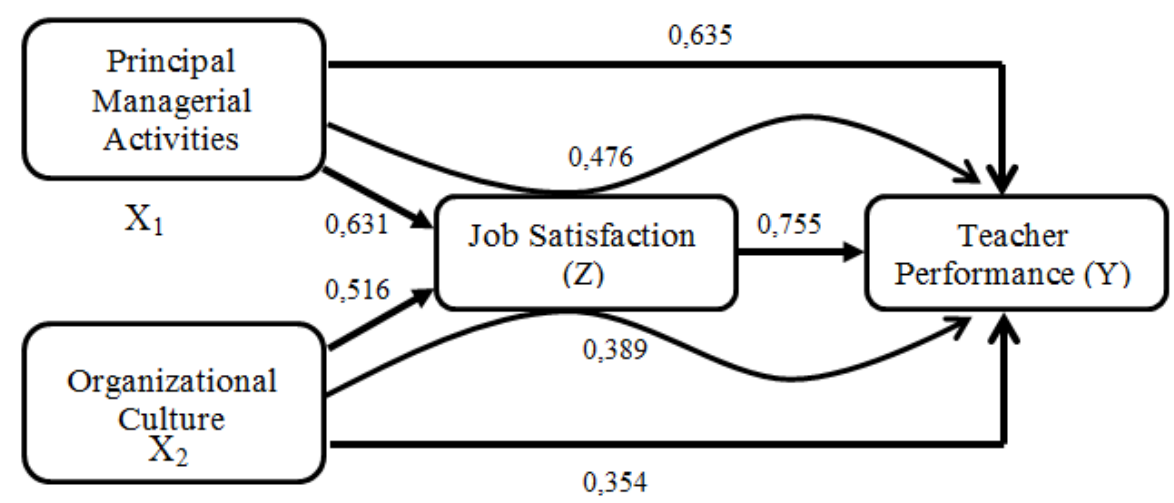

Figure 2. Final Relationship between Variables

The limitations of this study are: The study was conducted with the managerial activities of the principal, organizational culture, teacher performance and teacher job satisfaction, for teachers in the Hampang sub-district.

\section{Conclusion and Recommendation}

The principal's managerial activities, organizational culture, and job satisfaction directly influence the performance of teachers. While, organizational culture has a direct effect on job satisfaction of elementary school teachers in Hampang sub-district. The principal's managerial activities, and organizational culture, indirectly affect the performance of elementary school teachers.

School culture has a relationship with performance, communication has relationship with performance, school culture has a relationship with commitment, communication has a relationship with commitment, commitment has a relationship with teacher performance, commitment is an intermediary between the relationship between school culture and teacher performance and relationships communication with teacher performance.

\section{Acknowledgement}

The author thanks to Magister Program of Educational Management, Universitas Lambung Mangkurat, Banjarmasin for facilitating and supporting this research.

\section{References}

Aslamiah (2016). Membangun Pendidikan Berkualitas Melalui Peningkatan Kinerja Guru Sekolah Dasar, Prosiding Seminar Nasional PS2DMP UNLAM , 2(1), 2

Aslamiah, Agustina, I., \& Saleh, M. (2019). Relationship between the Principal Role, Motivation and Satisfaction with the Performance of Elementary School Teachers. Journal of K6, Education, and Management (J-K6EM), 2 (1), 87-96.

Bafadal. I, (2006). Manajemen peningkatan mutu sekolah dasar. Jakarta: Bumi Aksara

Damai, S., Efendi, R., \& Sulaiman, (2019). The Teacher Achievement Motivation as an Intervening Variable in Relationship between Teacher's Profesionalism, Principal's Leadership and Teacher's Performance of State High School in Banjarmasin City, Journal of K6, Education, and Management (J-K6EM), 2(1), 33-35. 
Darwito. (2008). Prilaku dalam organisasi. Terjemah Agus Dharma. Jakarta: Erlangga

Idris, J, (2005). Kompilasi pemeikiran pendidikan, Taufiqiyah Sa'adah Banda Aceh dan Suluh Press.Yogyakarta: Banda Aceh dan Yogyakarta

Mulyasa, (2004). Menjadi kepala sekolah professional. Bandung: PT Remaja Rusdakarya

Perie (1997). Manajemen pendidikan Indonesia, Jakarta: Rinika Cipta

Puspitasari, N. (2015). Kemampuan manajerial kepala sekolah dalam meningkatkan kinerja guru. Jurnal Informa Politeknik Indonusa Surakarta, 1(1), 29-36.

Rahmawati, E., Ahmad, K. I., \& Suriansyah,A. (2019). Relationship Between Emotional Intelligence, Spiritual Intelligence and Teacher Performance through Work Motivation as Intervening Variable in Islamic Elementary School in Banjarmasin, Indonesia, European Journal of Education Studies, 5 (11), 142-160.doi.10.5281/zenodo.2583976.

Robbins, S. P., (2001). Organization behavior (Terjemahan) Jilid 2, Edisi Ketujuh, Jakarta: PT. Bhuana Ilmu Populer

Suhaimi, \& Khalik A. (2018). Kepemimpinan transformasional kepala sekolah pada SMP
Muhammadiyah 4 Banjarmasin. Jurnal Penelitian Tindakkan dan Pendidikan, 4(1), $37-46$.

Suhardan, D. (2010). Supervisi profesional (layanan dalam meningkatkan mutu pembelajaran di era otonomi daerah), Bandung: Alfabeta

Suriansyah, A. (2014). Hubungan budaya sekolah, komunikasi, dan komitmen kerja terhadap kinerja guru Sekolah Dasar Negeri. Cakrawala Pendidikan: Jurnal Ilmiah Pendidikan, 33(3), 358-267.

Wati, N. W. K. W., Suriansyah, A., \& Effendi, M.R. (2017). Analisis faktor-faktor yang mempengaruhi kinerja dosen dalam proses belajar mengajar Program Studi DIV Bidan Pendidik Di STIKes Husada Borneo Banjarbaru, Jurnal Kesehatan Indonesia, 8(1), 39-45.

Wijaya C, \& Rusyam, (1994). Kemempuan dasar guru dalam proses belajar mengajar. Bandung: PT Remaja Rosdakarya

Wirawan, I. (2008). Kapita selekta, Teori kepemimpinan, pengantar untuk praktek dan penelitian. Jakarta: Kerja sama Yayasan Banun Indonesia \& UHAMKA Press. 